\title{
Food Extraction by the Males of Podisus nigrispinus (Dallas) (Hemiptera: Pentatomidae) from Cotton Leafworm Larvae
}

\author{
Alexandre Igor de Azevedo Pereira ${ }^{1}$, Francisco de Sousa Ramalho ${ }^{1 *}$, Karjoene Cassimiro \\ Vilar Rodrigues ${ }^{1}$, José Bruno Malaquias ${ }^{1}$, Jefferson Virgínio da Silva Souza ${ }^{1}$ and José Cola \\ Zanuncio $^{2}$ \\ ${ }^{1}$ Embrapa Algodão; Unidade de Controle Biológico; C.P. 174; 58107-720; Campina Grande - PB - Brasil. \\ ${ }^{2}$ Universidade Federal de Viçosa; Departamento de Biologia Animal; Viçosa - MG - Brasil
}

\begin{abstract}
In this work, the effect of different densities (1, 3, 5, 7 and 9) of 3rd instar Alabama argillacea (Huebner) larvae on food consumption by Podisus nigrispinus (Dallas) males was evaluated. The densities established were converted to weight of prey offered: $13.4 \mathrm{mg}$ (one larva), $33.3 \mathrm{mg}$ (three larvae), $54.3 \mathrm{mg}$ (five larvae), $81.8 \mathrm{mg}$ (seven larvae), and $110.34 \mathrm{mg}$ (nine larvae). The quantity of food consumed by P. nigrispinus increased with the prey density. The density of preys did not affect the time spent by the predator to ingest the food. The quantity of food extracted per minute was always higher in smaller densities and lower in higher densities. Males mean body weight did not differ statistically between the treatments tested, and weight gain was smaller in the first two densities tested. Relative consumption rates increased with the quantity of larvae offered. P. nigrispinus males might change its predatory behavior as a function of the quantity of prey available.
\end{abstract}

Key words: Cotton leafworm, predator, stinkbug, food consumption, nutrition

\section{INTRODUCTION}

Cotton leafworm, Alabama argillacea (Huebner) (Lepidoptera: Noctuidae) is the main cotton leaf pest in Brazil (Bleicher, 1993; Ramalho, 1994; Silva et al., 1997), which is usually controlled by the pesticide (Malaquias et al., 2009), being their larvae the main biological target (Ramalho, 1994). One of the promising alternatives to reduce the use of chemicals in the agricultural ecosystems is the integration between the natural enemies (predators and parasitoids) and selective pesticides (Pereira et al., 2005).

Predaceous stinkbugs (Hemiptera: Pentatomidae,
Asopinae) are still neglected in agricultural practices, because the only species of this group in commercial use for biological pest control in North America and Europe is Podisus maculiventris (Say) (De Clercq, 2000). However, these predators have a promising future in the control of agricultural and forest pests of economical importance. Among these species are $P$. maculiventris and Perillus bioculatus (Fabricius) in North America and Europe, and Podisus nigrispinus (Dallas) in South America (Medeiros et al., 2004). Podisus nigrispinus is one of the most common species of Asopinae studied in the Neotropical region (De Clercq, 2000), and

* Author for correspondence: framalho@cnpa.embrapa.br 
has been reported in several countries of South and Central America (Thomas, 1992; Medeiros et al., 2004; Lemos et al., 2005) as an important biological control agent in different crops.

Although P. nigrispinus is one of the most studied species, there is still little information on its feeding behavior when submitted to different quantities of prey. Food consumption and its utilization are basic needs for the growth, development, and reproduction of all organisms. The energy obtained is either compromised or already destined to the maintenance of certain metabolic processes, when the source of food becomes scarce or nutritionally poor (Legaspi and Legaspi, 1998). The feeding regime may change the life cycle of predaceous pentatomids, as wellfed individuals reproduce better and more frequently (Engelmann, 1970; Lenski, 1984; Lemos et al., 2001). The quantity of ingested food certainly depends on the predator's ability in detecting, capturing, and killing their preys. These skills reflect the differences in response of several species of predators and their preys (Holling, 1961). Thus each predator can have different types of behavior in relation to the density of preys. The number of individuals attacked by a predator in a certain density of preys depends on the success of the attacks, the time in which the prey is exposed to the predator, and the handling time of each prey (Holling, 1966).

Studies discussing the existing relation between the number of preys captured by the predators compared to the density of preys, known as functional response (Holling, 1966; Mills, 1982), are important for a better understanding of the relation between the predator and prey. The behavior of predators of the genus Podisus in relation to their preys have been studied by Tostowaryk (1972) and Hokyo and Kawauchi (1975); however, little is known about the predatory behavior of $P$. nigrispinus when submitted to different densities of prey.

In light of the importance of $P$. nigrispinus, it is surprising how little attention has been paid to predatory capacity of $P$. nigrispinus and its impact on cotton leafworm in Brazil. Therefore, this work studied of effect of prey density, A. argillacea larvae on food extraction by $P$. nigrispinus male predators in the laboratory.

\section{MATERIALS AND METHODS}

The specimens of predator $P$. nigrispinus and its prey $A$. argillacea were kept in environmental chambers at constant temperature of $26 \pm 1^{\circ} \mathrm{C}, \mathrm{RH}$ of $60 \pm 10 \%$, and a photoperiod of 12:12 (L:D) h. Fifth instar nymphs of $P$. nigrispinus with fortyeight-hour-old were removed from the rearing cage and transferred to transparent plastic cups $(500 \mathrm{~mL})$, with 10 nymphs per cup in environmental chambers. A $2.5 \mathrm{~mL}$ plastic tube with distilled water was inserted through each cup lid to keep the moisture inside the cups. A total of 130 nymphs from the 5th instar of the predator were used. Each nymph received as diet two 3rd instar cotton leafworm larvae offered daily per cup. The quantification of newly emerged adults was made every $24 \mathrm{~h}$. After the emergence, virgin adult males were individualized in $100 \mathrm{~mL}$ plastic cups with $2.5 \mathrm{ml}$ plastic tubes inserted through their lids for water supply and moisture. All the adult males used in the experiment remained $24 \mathrm{~h}$ without food after individualization, and then weighed on an analytical scale $( \pm 0.1 \mathrm{mg})$ "Mettler H31AR".

A randomized complete-block design was used in the study, with five treatments: (1) one larva of $A$. argillacea (mean weight $=13.40 \mathrm{mg}$ ); (2) three larvae of $A$. argillacea (mean weight $=33.30 \mathrm{mg}$ ); (3) five larvae of $A$. argillacea (mean weight = $54.30 \mathrm{mg}$ ); (4) seven larvae of $A$. argillacea (mean weight $=81.80 \mathrm{mg}$ ), and (5) nine larvae of $A$. argillacea $($ mean weight $=110.34 \mathrm{mg})$, distributed in four replications; each experimental unit comprised of five $P$. nigrispinus males individually in $100 \mathrm{~mL}$ plastic cups. The first assessments were carried out every 15 minutes during the first $12 \mathrm{~h}$, to estimate the ingestion time quantified from the time the predator inserted part of its mouth apparatus into the prey's body, paralyzing the prey until the predator's mouth withdrawal from the prey's body. The other assessments were carried out every $24 \mathrm{~h}$, which consisted of quantifying the number of totally larvae preyed (only the exoskeleton remained), partially preyed larvae (exoskeleton and part of hemolymph was left), remaining larvae (living larvae that escaped from preying), and the weight of larvae exposed to the predator on a daily basis. The larvae preyed were identified by features, such as deformations and discoloration, according to O'Neil (1989).

The quantity of larvae consumed by predator $(\mathrm{Na})$ and the quantity of food extracted by the predator per prey $(\mathrm{Fe})$ were estimated with the data 
registered. From the quantity of food extracted by the predator per prey $(\mathrm{Fe})$, what was left from each prey after ingestion (Rf) was estimated through the formula $\mathrm{Rf}=\mathrm{P}-\mathrm{Fe}$ (Holling, 1966), where $\mathrm{P}$ was the weight of each prey. The gain of weight per predator was estimated through the difference between the predator's weight at the beginning and at the end of nine days. Relative consumption rate (RCR) was also estimated through the formula $\mathrm{TCR}=\mathrm{Na} / \mathrm{Pm} \cdot \mathrm{T}$ (Waldbauer, 1968), where Pm was the mean predator weight gain in $24 \mathrm{~h}(\mathrm{~T})$. The quantity of food extracted by minute $\left(\mathrm{Fe}_{\min }\right)$ were estimated from the quantity of food extracted per prey $(\mathrm{Fe})$ by the formula $\mathrm{Fe}_{\text {min }}=\mathrm{Fe} / \mathrm{Ti}$ $\left(\mathrm{mg} \cdot \mathrm{min}^{-1}\right)($ Cohen, 1990), where $\mathrm{Ti}$ was the time taken by the predator to extract the food.

The data were submitted to variance analysis (SAS Institute, 2006), and the means were compared by Student-Newman-Keuls test $(P=0.05)$. The data were also submitted to regression analysis $(P=$ 0.05) (SAS Institute, 2006).

\section{RESULTS AND DISCUSSION}

There was an increase in the number of larvae consumed $(\mathrm{Na})$ with the increase in density of larvae offered to the predator $(\mathrm{F}=35.19 ; P=0.05)$ (Table 1). The percentage of food larvae consumed by predator decreased as it was submitted to larger quantities of prey $(\mathrm{F}=10.17 ; P$ $=0.05)$ (Table 1), being this relationship described by a quadratic function $\left(\mathrm{F}=16.95 ; P=0.05 ; R^{2}=\right.$ 0.94) (Fig. 1). Rocha et al. (2002) also found similar results, showing an increase in the amount of food consumed and a decrease in the percentage of prey consumed by the females of Cosmoclopius nigroannulatus (Stal) (Hemiptera: Reduviidae) as the density of nymphs Spartocera dentiventris (Berg) (Hemiptera: Coreidae) from the 1st instar increased. According to Mukerji and LeRoux (1969), the increase in daily consumption of nymphs of $P$. maculiventris was proportional to the amount of prey available. When nymphs or adults of $P$. maculiventris and $P$. sagitta were submitted to higher densities of prey under laboratory conditions, they attacked and preyed more individuals than they needed to meet their eating needs (De Clercq and Degheele, 1994). Hokyo and Kawauchi (1975) reported that the quantity of larvae of Spodoptera litura (Fabricius) consumed by $P$. maculiventris was greater as the food offer increased. Predators are more likely to find their prey more frequently in higher densities of prey than in lower densities, which stimulates greater efforts in attack, and thus neglects the hunger effect in preying (Holling, 1966).

A reduction in the quantity of food extracted by $P$. nigrispinus male from each attacked larva was detected as the quantity of prey offered increased $(\mathrm{F}=16.38 ; \quad P=0.05)$, with this relationship described by a cubic function $(\mathrm{F}=16.12 ; P=0.05$; $R^{2}=0.99$ (Fig. 2). The stabilization of the quantity of food extracted from each prey (33.3 mg of prey available) (Table 1) could be possibly related to the quantity of food required by the predator to remain or become satiated. According to Pereira et al. (2008), the quantity of food consumed and extracted by $P$. nigrispinus females from each larva of $A$. argillacea decreased as the food available increased.

The greatest quantity and percentage of food extracted from each attacked prey by $P$. nigrispinus was observed with one A. argillacea larva (13.4 mg) per P. nigrispinus male (Table 1). The quantity of food required to satiate the predator Linyphia triangularis Clerck (Araneae: Linyphidae) was similar to its gut capacity in low food regimens (Turnbull, 1962). However, the predator continued attacking prey even when the stimulus caused by hunger and the quantity required to remain satiated were low at high prey densities when the opportunity to capture them was higher (Turnbull, 1962). Food intake in other predatory species has been shown to be related to the number of prey available (Cook and Cockrell, 1978). This indicated that the values obtained in present work for consumed larvae $(\mathrm{Na}(\%))$ and food extracted from each larva $(\mathrm{Fe}(\%))$ by $P$. nigrispinus males (Table 1) were similar to those reported by other researchers for other predatory species. It was possible that the reduction in the food mass and in the percentage extracted from each prey could be related to the frequency of prey encounter, the hunger of the predators or a combination of both factors. On the other hand, predators with low prey availability normally did not use fill their gut capacities (Griffiths, 1982). Thus, the predator's hunger tends to increase when fewer prey are available leading to ingestion of more food from each one (Charnov, 1976). However, the quantity of food a predator ingests per prey is reduced as the abundance of prey increases (Cook and Cockrell, 1978). This behavior may be a direct response to the frequency 
with which prey are encountered or may operate indirectly via the hunger level of the predator or from a combination of the two (Cook and Cockrell, 1978).

According to Turnbull (1962), in lower feeding regimes, opportunities of attack are limited, which makes the predator even hungrier, ingesting a quantity of food that is closer to its gut capacity. On the other hand, in higher densities of prey, the predator is provided with more feeding opportunities, even when there is little stimulus triggered by hunger. This makes the quantity of food required by the predator much smaller to return to satiation stage, and reduced food extraction.

O'Neil (1997) described different predatory rates of $P$. maculiventris under field and laboratory conditions. He reported that the functional response of this predator when feeding on Leptinotarsa decemlineata (Say) (Coleoptera: Crysomelidae) larvae in the field was not similar to that quantified in laboratory; in the field, predators seemed to attack a constant number of preys, regardless of the density available. In laboratory, the number of preys attacked increased with density. Mukerji and LeRoux (1969) reported that in field conditions, $P$. maculiventris preyed fewer individuals of bigger size and a larger quantity of smaller preys, thus suggesting that the predator can indirectly guarantee the survival of its species of prey, including the prey's ability in resisting to the predator's attack. This may probably be a factor responsible for the coexistence between the predator and prey in the agro-ecosystems (Azevedo and Ramalho, 1999).

Table $1-$ Mean $^{1}( \pm \mathrm{SE})$ of consumed larvae $\left(\mathrm{N}_{\mathrm{a}}\right)$, food extracted from each larva $\left(\mathrm{F}_{\mathrm{e}}\right)$, time taken to ingest the food $\left(\mathrm{T}_{\mathrm{i}}\right)$, and food extracted per minute $\left(\mathrm{Fe}_{\min }\right)$ per adult male of Podisus nigrispinus submitted to different densities of 3rd-instar Alabama argillacea larvae.

\begin{tabular}{|c|c|c|c|c|c|c|}
\hline \multirow{2}{*}{$\begin{array}{c}\text { Larva } \\
\text { density (n) }\end{array}$} & \multicolumn{2}{|c|}{$\mathbf{N a}$} & \multicolumn{2}{|c|}{$\mathbf{F e}$} & \multirow{2}{*}{$\underset{(\mathbf{m i n})}{\mathbf{T i}}$} & \multirow{2}{*}{$\begin{array}{c}\text { Fe } \\
\left(\text { mg.min }^{-1}\right)\end{array}$} \\
\hline & (mg) & $(\%)$ & (mg) & $(\%)$ & & \\
\hline 1 & $9.13 \pm 0.79 \mathrm{c}$ & $68.10 \pm 5.88 \mathrm{a}$ & $9.13 \pm 0.79 a$ & $68.10 \pm 5.88 a$ & $267.25 \pm 32.12 \mathrm{a}$ & $0.034 \pm 0.003 a$ \\
\hline 3 & $14.04 \pm 1.58 \mathrm{c}$ & $42.15 \pm 4.74 b$ & $4.68 \pm 0.53 b$ & $42.16 \pm 4.74 b$ & $306.88 \pm 39.13 a$ & $0.015 \pm 0.002 b c$ \\
\hline 5 & $18.62 \pm 1.86 \mathrm{c}$ & $35.31 \pm 3.26 b$ & $3.84 \pm 0.36 b$ & $35.31 \pm 3.28 b$ & $278.13 \pm 37.30 \mathrm{a}$ & $0.014 \pm 0.001 \mathrm{c}$ \\
\hline 7 & $30.67 \pm 1.72 b$ & $37.50 \pm 2.10 \mathrm{~b}$ & $4.38 \pm 0.25 b$ & $37.47 \pm 2.11 b$ & $253.00 \pm 29.87 \mathrm{a}$ & $0.018 \pm 0.001 b c$ \\
\hline 9 & $42.62 \pm 5.02 \mathrm{a}$ & $38.63 \pm 4.55 b$ & $4.74 \pm 0.56 b$ & $38.62 \pm 4.56 \mathrm{~b}$ & $213.50 \pm 26.98 \mathrm{a}$ & $0.022 \pm 0.002 b$ \\
\hline $\mathrm{F}=$ & $\begin{array}{c}35.19 \\
(P=0.05)\end{array}$ & $\begin{array}{c}10.17 \\
(P=0.05)\end{array}$ & $\begin{array}{c}16.38 \\
(P=0.05)\end{array}$ & $\begin{array}{c}9.82 \\
(P=0.05)\end{array}$ & $\begin{array}{c}0.99 \\
(P>0.05)\end{array}$ & $\begin{array}{c}17.28 \\
(P=0.05)\end{array}$ \\
\hline
\end{tabular}

${ }^{\mathrm{T}}$ Within columns, means followed by a common letter do not differ significantly by the Student-Newman-Keuls test $(P=0.05)$.

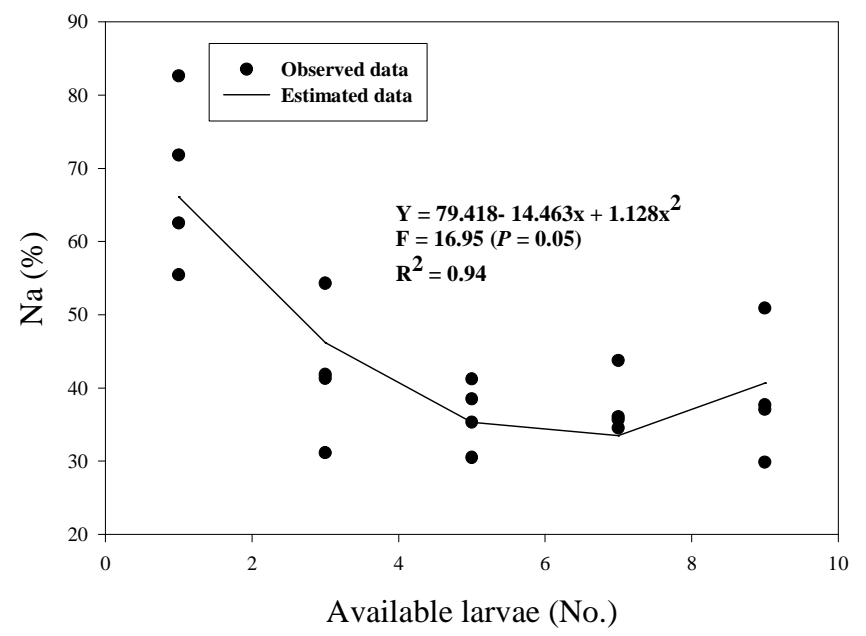

Figure 1 - Relationship between the number of Alabama argillacea larva availables and the percentage of larvae predated $\left(\mathrm{N}_{\mathrm{a}}, \%\right)$ by Podisus nigrispinus. 


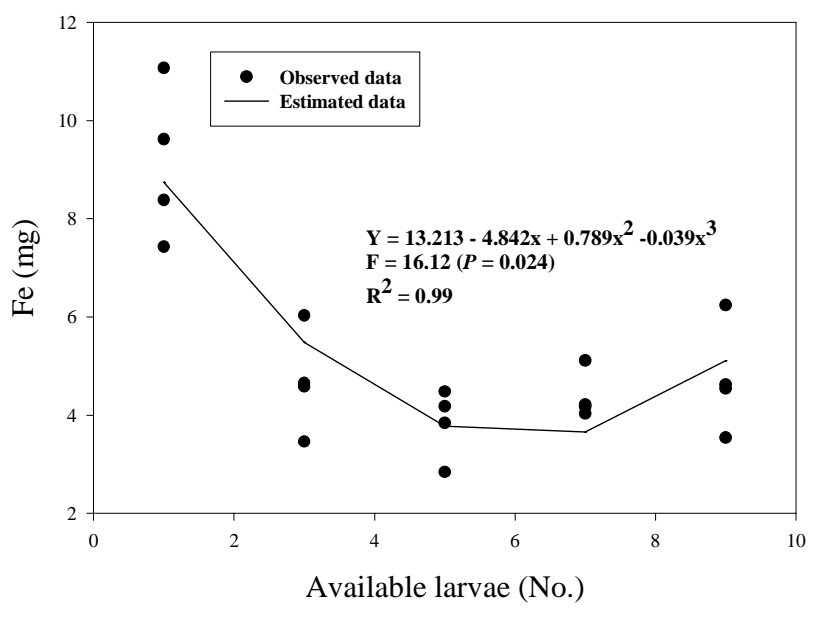

Figure 2 - Relationship between the number of Alabama argillacea available and the quantity of food extracted from each larva $\left(\mathrm{F}_{\mathrm{e}}, \mathrm{mg}\right)$ by Podisus nigrispinus.

O’Neil (1997) observed that under laboratory conditions, the area in which $P$. maculiventris used to search for food decreased as the density of $L$. decemlineata increased, due to the time the predator spent on handling the prey. HoughGoldstein et al. (1966), comparing the preying of Perillus bioculatus (Fabricius) and $P$. maculiventris on $L$. decemlineata in field and laboratory studies, found that the limited space under laboratory conditions was a key factor for greater preying by these organisms.

The maximum mass of $A$. argillacea larvae consumed $(\mathrm{Na})$ by $P$. nigrispinus males with the increase of density could be attributed to the conditions, as predators were more exposed to preys and, therefore explored a smaller area and spent less time searching and handling the prey and/or extracting food. Males of $P$. nigrispinus spent $24 \mathrm{~h}$ without food before meeting its prey, which could have probably triggered the predator's hunger, and interfered in its attack skills.

It was observed that the density of preys did not affect the time spent by the predator to ingest the food $(\mathrm{F}=0.99 ; P>0.05)$ (Table 1$)$. Prey ingestion time $\left(\mathrm{T}_{\mathrm{i}}\right)$ is an important component of handling time by the predator and it can vary with the abundance or size of the prey, and the hunger level of the predator (Holling, 1966). Similar results were reported by Cook and Cockrell (1978), when studying the feeding behavior of Adalia bipunctata (Linnaeus) (Coleoptera: Coccinellidae) on nymphs and adults of Acyrthosiphon pisum (Harris)
(Hemiptera: Aphididae). This was also reported in the predator Zelus renardii (Kolenati) (Heteroptera: Reduviidae), where ingestion time was positively related to the weight of Heliothis virescens (Fabricius) (Lepidoptera: Noctuidae) larvae (Ables, 1978). This could not be related to the quantity of preys offered, but rather with their size, as the preys offered were all from the 3 rd stage and, therefore, of similar size and weight.

In present work, $P$. nigrispinus males took $263.75 \pm 34.93 \mathrm{~min}$ to ingest $72.8 \mathrm{mg}$ of larvae in $A$. argillacea. According to Cohen (1990), ingestion time is quite variable among other Heteropteran predators: $89.5 \mathrm{~min}$ to feed on $1.5 \mathrm{mg}$ of larvae in Geocoris punctipes (Say) (Heteroptera: Lygaeidae), $159 \mathrm{~min}$ to feed on $93.1 \mathrm{mg}$ of larvae in P. maculiventris, $127 \mathrm{~min}$ to feed on $65.8 \mathrm{mg}$ of larvae in Z. renardii, and 149.9 min to feed on $48.6 \mathrm{mg}$ of larvae in Sinea confuse Caudell (Heteroptera: Reduviidae). This indicated that $P$. nigrispinus males had a longer ingestion period and relatively long handling time with this prey. Furthermore, it would have a longer digestion pause and capture periods following prey preparation, with decrease in the search and attack capacity. Predators do not attack prey of all age and size classes with the same frequency, and some of them may be immune to attack (Price, 1975). Thus the predators would be likely to have a smaller impact on a larger prey population. Podisus nigrispinus attacks a wide diversity of prey, including those of different sizes but predators of this genus can exhibit short capture 
and preparation times (Cohen and Tang, 1997), increasing search activities and consequently occur new attacks with high impact on the prey population (Waldbauer, 1968; Hough-Goldstein et al., 1996).

Podisus nigrispinus, a generalist predator, attacks preys of different species and sizes. According to Cohen and Tang (1997), when predators are bigger than their preys, the time spent on capturing and handling the prey is substantially reduced, thus being more flexible in relation to the time spent on the food extraction process. In addition, as search activities increase, new attacks take place and a more efficient achievement in the population of preys is obtained. It is also suggested that, for predators, the size of the prey may be more advantageous than its abundance, thus saving time and energy that would be applied in search activities. Then, it is believed that releases of $P$. nigrispinus against $A$. argillacea should be preferably directed at reaching larvae from first stages, as predators would spend less time handling the prey and could attack a greater number of individuals.

The quantity of food extracted by the male predator per minute decreased when the number of prey available increased $(\mathrm{F}=17.28 ; P=0.05)$ (Table 1). These results are in accordance with the theory of optimal foraging, which establishes the maximization or reduction in consumption rate, increasing or decreasing handling time or extraction efficiency according to the availability of preys. On the other hand, this probably occurred because A. argillacea larvae clustered in groups at high densities that made it difficult for $P$. nigrispinus to attack the prey. Similar results were reported by Holling (1966) and Charnov (1976) for Hierodula crassa (Saussune) (Orthoptera: Mantidae) with the larvae Drosophila melanogaster (Linnaeus) (Diptera: Drosophilidae) and Musca domestica (Linnaeus) (Diptera: Muscidae). This was also reported for Podisus modestus (Dallas) (Heteroptera: Pentatomidae) with the prey Neodiprion swainei Middleton and $N$. pratti banksianae Rohwer (Hymenoptera, Neodiprionidae) (Tostowaryk, 1972). This would reduce the food extraction efficiency and increase the handling time in high prey densities as suggested by the optimal foraging hypothesis (Charnov, 1976). This was shown for Hierodula crassa Saussune (Orthoptera: Mantidae) on Drosophila melanogaster Linné (Diptera:
Drosophilidae) and Musca domestica Linné (Diptera: Muscidae) larvae (Holling, 1966; Charnov, 1976).

The effect of the prey density on the percentage of prey consumed by $P$. nigrispinus males depended of the adult age $\left(\mathrm{F}_{(\text {age }} \times\right.$ density $\left.)=3.98 ; P=0.05\right)$ (Table 2). Predator age also affected the consumption rates of predator $C$. nigroannulatus between their first and fifth days of life (Rocha et al., 2002). This could be due to physiological changes, and therefore, it was not dependent on the quantity of food consumed (Morris, 1963). Probably, it could be related to the reduction on the energy demands as the age of theses predators and the energy body stored in their body increased (Mukerji and Leroux, 1969).

The relative consumption rate $(\mathrm{F}=23.20 ; P=0.05)$ of the males of the predator $P$. nigrispinus increased with the quantity of prey available, and the daily weight gain $(\mathrm{F}=6.16 ; P=0.05)$ increased from the density of 1 larva/predator to 5 larvae/predator; however, its body weight was not affected by the quantity of prey available $(\mathrm{F}=2.65$; $P>0.05$ ) (Table 3). Holling (1966) found similar results when evaluating the consumption of larvae of D. melanogaster by the females of the predator H. crassa throughout 18 days. According to Rocha et al. (2002), the consumption by the males of the Reduviidae $C$. nigroannulatus from 1 st to 5 th day of life was affected by the density and the age of the prey. This could be related to the demand of energy required for the development of reproductive structures and sexual activity, leading them to eventually ingest a greater quantity of food, resulting on a greater gain of weight (Holling, 1966). On the other hand, probably, it was also due to the reduction on the energy demands as the age of these predators and the energy stored in their body increased (Mukerji and LeRoux, 1969).

The decrease of food consumption could be related to their adults' physiological capacity in storing fat, which was gradually consumed and wasted by means of energy in order to meet the last stage of satiation. Morris (1963) reported a decrease in the number of preys attacked in the same proportion as the predator got older. According to Morris (1963), preying rate by $P$. maculiventris decreased substantially with the adults' age, presumably as a result of physiological changes that did not depend on the quantity of food consumed. 
Table 2 - Daily consumption $(\%)^{1}$ (means \pm SE) of Alabama argillacea larvae by adult of Podisus nigrispinus males at different ages submitted to different densities of 3rd-ínstar Alabama argillacea larvae throught nine days of life.

\begin{tabular}{cccccc}
\hline $\begin{array}{c}\text { Age } \\
\text { (day) }\end{array}$ & $\mathbf{1}$ & \multicolumn{4}{c}{ Larva density (n) } \\
\cline { 2 - 6 } & $47.67 \pm 32.63 \mathrm{Aa}$ & $40.92 \pm 13.54 \mathrm{ABa}$ & $40.95 \pm 17.55 \mathrm{Aa}$ & $37.01 \pm 8.48 \mathrm{Aa}$ & $46.20 \pm 7.28 \mathrm{Aa}$ \\
\hline 1 & $63.06 \pm 31.84 \mathrm{ABb}$ & $61.43 \pm 25.81 \mathrm{Bb}$ & $45.27 \pm 8.55 \mathrm{Aab}$ & $30.88 \pm 8.47 \mathrm{Aa}$ & $36.88 \pm 14.22 \mathrm{Aa}$ \\
2 & $71.20 \pm 24.31 \mathrm{ABb}$ & $26.02 \pm 13.34 \mathrm{Aa}$ & $33.21 \pm 7.53 \mathrm{Aa}$ & $33.09 \pm 9.61 \mathrm{Aa}$ & $42.62 \pm 20.31 \mathrm{Aa}$ \\
3 & $74.10 \pm 21.51 \mathrm{ABb}$ & $37.30 \pm 16.62 \mathrm{ABa}$ & $27.68 \pm 12.83 \mathrm{Aa}$ & $36.51 \pm 7.82 \mathrm{Aa}$ & $31.41 \pm 6.97 \mathrm{Aa}$ \\
4 & $90.05 \pm 3.50 \mathrm{Bb}$ & $33.10 \pm 28.84 \mathrm{ABa}$ & $47.71 \pm 13.59 \mathrm{Aa}$ & $39.94 \pm 7.95 \mathrm{Aa}$ & $40.37 \pm 7.07 \mathrm{Aa}$ \\
5 & $64.20 \pm 31.02 \mathrm{ABa}$ & $53.63 \pm 6.29 \mathrm{ABa}$ & $39.50 \pm 11.17 \mathrm{Aa}$ & $39.83 \pm 3.67 \mathrm{Aa}$ & $42.88 \pm 7.92 \mathrm{Aa}$ \\
6 & $87.05 \pm 11.45 \mathrm{Bc}$ & $59.21 \pm 22.55 \mathrm{Bb}$ & $35.19 \pm 11.87 \mathrm{Aa}$ & $41.40 \pm 8.25 \mathrm{Aab}$ & $33.07 \pm 12.52 \mathrm{Aa}$ \\
7 & $56.31 \pm 31.35 \mathrm{Aa}$ & $52.43 \pm 16.42 \mathrm{ABa}$ & $35.57 \pm 10.95 \mathrm{Aa}$ & $40.93 \pm 12.65 \mathrm{Aa}$ & $32.59 \pm 7.48 \mathrm{Aa}$ \\
8 & $92.20 \pm 3.52 \mathrm{Bb}$ & $41.12 \pm 16.44 \mathrm{ABa}$ & $36.38 \pm 8.13 \mathrm{Aa}$ & $44.71 \pm 3.73 \mathrm{Aa}$ & $39.72 \pm 10.33 \mathrm{Aa}$
\end{tabular}

${ }^{1}$ Student-Newman-Keuls test: for each predator age or prey weight, means with the same lower case (with the same predator age) or capital letter (within the same prey weight), respectively, are not different from each other $(P=0.05)$. Predator age vs prey density $(\mathrm{F}=3.98 ; P=0.05)$.

Table 3 - Mean values ${ }^{1}( \pm$ SE) of the weight gain, mean body weight (in 24 h) and relative consumption rate (RCR) per Podisus nigrispinus adult male under different prey densities

\begin{tabular}{cccc}
\hline $\begin{array}{c}\text { Larva } \\
\text { density (n) }\end{array}$ & $\begin{array}{c}\text { Weight gain } \\
\text { (mg/9 days) }\end{array}$ & $\begin{array}{c}\text { Mean body weight } \\
(\mathbf{m g})\end{array}$ & $\begin{array}{c}\text { RCR (mg prey /mg } \\
\text { predator/day) }\end{array}$ \\
\hline 1 & $1.80 \pm 0.20 \mathrm{~b}$ & $24.96 \pm 1.07 \mathrm{a}$ & $0.37 \pm 0.04 \mathrm{c}$ \\
3 & $3.91 \pm 0.51 \mathrm{ab}$ & $27.47 \pm 1.13 \mathrm{a}$ & $0.52 \pm 0.07 \mathrm{c}$ \\
5 & $6.73 \pm 0.91 \mathrm{a}$ & $26.54 \pm 0.93 \mathrm{a}$ & $0.70 \pm 0.06 \mathrm{c}$ \\
7 & $6.60 \pm 0.51 \mathrm{a}$ & $29.38 \pm 1.50 \mathrm{a}$ & $1.06 \pm 0.08 \mathrm{~b}$ \\
9 & $5.78 \pm 1.63 \mathrm{a}$ & $28.75 \pm 0.57 \mathrm{a}$ & $1.48 \pm 0.16 \mathrm{a}$ \\
\hline $\mathrm{F}=$ & $6.16(P=0.05)$ & $2.65(P=0,05)$ & $23.20(P=0,05)$ \\
\hline
\end{tabular}

${ }^{\mathrm{T}}$ Within columns, means followed by a common letter do not differ significantly by the Student-Newman-Keuls test $(P=0.05)$.

Male predators of $P$. nigrispinus could be considered efficient control agents of 3rd instar $A$. argillacea larvae, responding positively when exposed to different quantity of preys, and spending less time handling or preparing the prey. However, realistic field experiments are needed to elucidate the tritrophic relationships among $P$. nigrispinus males, their prey and host plants.

\section{ACKNOWLEDGMENTS}

This study was supported by the funds from the CNPq - Conselho Nacional de Desenvolvimento Científico e Tecnológico (CNPq) and FAPEMIG Fundação de Amparo à Pesquisa do Estado de Minas Gerais.

\section{RESUMO}

O efeito de diferentes densidades (1, 3, 5, 7 e 9) de lagartas do $3^{\text {o }}$ instar de Alabama argillacea (Huebner) no consumo de alimento por machos de Podisus nigrispinus (Dallas) foi avaliado em condições de laboratório. As densidades utilizadas foram convertidas a peso de presa oferecida: 13,40 mg (1 lagarta), $33.30 \mathrm{mg}$ (3 lagartas), 54,30 mg (5 lagartas), $81,80 \mathrm{mg}$ (7 lagartas) e $110,34 \mathrm{mg}$ (9 lagartas). A quantidade de alimento consumido pelo macho de $P$. nigrispinus aumentou com a densidade da presa. A densidade da presa não afetou o tempo gasto pelo predador para ingerir o alimento. A quantidade de alimento extraído por minuto pelo predador foi sempre maior nas mais baixas densidades e menores nas mais altas 
densidades. O peso corpóreo médio dos machos de $P$. nigrispinus não difereriu entre os tratamentos testados e o seu ganho de peso foi menor nas duas primeiras densidades testadas. As taxas de consumo relativo aumentaram com a quantidade de lagartas oferecidas. Os machos de $P$. nigrispinus podem mudar seu comportamento predatório em função da quantidade de presas disponíveis.

\section{REFERENCES}

Ables, J.R. (1978), Feeding behavior of an assassin bug, Zelus renardii. Ann. Entomol. Soc. Am., 71, 476-478.

Azevedo, F.R. and Ramalho, F.S. (1999), Efeitos da temperatura e da defesa da presa no consumo pelo predador Supputius cincticeps (Stal) (Heteroptera: Pentatomidae). Pesq. Agropec. Bras., 34, 165-171.

Bleicher, E. (1993), Importância relativa das principais pragas do algodoeiro em alguns estados do Brasil. An. Soc. Entomol. Brasil, 22, 553-562.

Charnov, E.L. (1976), Optimal foraging: attack strategy of a mantid. Am. Natural., 110, 141-151.

Cohen, A.C. (1990), Feeding adaptations of some predaceous hemiptera. Ann.Entomol. Soc. Am., 83, 1215 1223.

Cohen, A. C. and Tang, R. (1997), Relative prey weight influences handling time and biomass extraction in Sinea confusa and Zelus renardii (Heteroptera: Reduviidae). Environ. Entomol., 26, 559-565.

Cook, R.M. and Cockrell, B.J. (1978), Predator ingestion rate and its bearing on feeding time and the theory of optimal diets. J. Anim. Ecol., 47, 529-547.

De Clercq, P. (2000), Predaceous stinkbugs (Pentatomidae: Asopinae). In Schaefer, C.W. and A.R. Panizzi, Heteroptera of Economic Importance. 1o ed. Cambridge: Cambridge University. p.737-789.

De Clercq, P. and Degheele, D. (1994), Laboratory measurement of predation by Podisus maculiventris

and Podisus sagitta (Heteroptera: Pentatomidae) on beet armyworm (Lepidoptera: Noctuidae). J. Econ. Entomol., 87, 76-83.

Engelmann, F. (1970), Factors that affect egg production and fecundity. In Engelmann, F. The Physiology of Insects Reproduction. Oxford: Pergamon Press. p.107-142.

Griffiths, D. (1982), Tests of alternative models of prey consumption by predators, using ant-lion larvae. J. Anim. Ecol. 52:363-373.

Hokyo, N. and Kawauchi, S. (1975), The effect of prey size and prey density on the functional response, survival, growth and development of a predatory pentatomid bug, Podisus maculiventris. Res. Popul. Ecol., 16, 207-218.

Holling, C.S. (1961), Principles of insect predation. Annu. Rev. Entomol., 6,163-182.
Holling, C.S. (1966), The functional response of invertebrate predators to prey density. Mem. Entomol. Soc. Can., 48, 5-86.

Hough-Goldstein, J., Cox, J. and Armstrong, A. (1996), Podisus maculiventris (Heteroptera: Pentatomidae) predation on ladybird beetles (Coleoptera: Coccinelidae). Fla. Entomol., 79, 64-68.

Legaspi, J.C. and Legaspi, B.C. (1998), Life history trade-offs in body weights, egg loads, and fat reserves of field-collected Podisus maculiventris (Heteroptera: Pentatomidae). In Coll, M. and Ruberson, J.R. Predatory heteroptera: Their ecology and use in biological control. Lanham: Proc. Thomas Say Publ. Entomol. Entomol. Soc. Am., 71-87.

Lemos, W.P., Medeiros, R.S., Ramalho, F.S. and Zanuncio, J.C. (2001), Effects of plant feeding on the development, survival and reproduction of Podisus nigrispinus (Heteroptera: Pentatomidae). Intern. J. Pest Manag., 47, 89-93.

Lemos, W.P., Ramalho, F.S., Serrão, J.E., Zanuncio, J.C. (2005), Morphology of female reproductive tract of the predator Podisus nigrispinus (Dallas)(Heteroptera: Pentatomidae) fed on different diets. Braz. Archiv. Biol. Technol. 48, 129-138.

Lenski, R.E. (1984), Food limitation and competition: a field experiment with two Carabus species. Jour.Anim. Ecol., 53, 203-216.

Malaquias, J.B., Ramalho, F.S., Fernandes, F.S., Souza, J.V.S. and Azeredo, T.L. (2009), Effects of photoperiod on the development and growth of Podisus nigrispinus, a predator of cotton leafworm. Phytoparasitica, 37; 241-248.

Medeiros, R.S., Ramalho, F.S., Serrão, J.E. and Zanuncio, J.C. (2004), Estimative of Podisus nigrispinus (Dallas)(Heteroptera: Pentatomidae) development time with non linear models. Neotrop. Entomol., 33, 141-148.

Mills, N.J. (1982), Satiation and the functional response: A test of a new model. Ecol. Entomol., 7, 305-315.

Morris, R.F. (1963), The effect of predator age and prey defense on the functional response of Podisus maculiventris Say to the density of Hyphantria cunea Drury. Can. Entomol., 95, 1009-1020.

Mukerji, M.K. and LeRoux, E.J. (1969), The effect of predator age on the functional response of Podisus maculiventris to the prey size of Galleria mellonella. Can. Entomol., 101, 314-327.

ONeil, R.J. (1989), Comparison of laboratory and field measurements of the functional response of Podisus maculiventris (Heteroptera: Pentatomidae). J. Kan. Entomol. Soc., 62, 148-155.

O'Neil, R. J. (1997), Functional response and search strategy of Podisus maculi ventris (Heteroptera: Pentatomidae) attacking Colorado Potato Beetle (Coleoptera: Chrysomelidae). Environ. Entomol., 26, 1183- 1190. 
Pereira, A.I.A., Ramalho, F.S., Zanuncio, J.C. (2005), Susceptibility of Podisus nigrispinus (Dallas)(Heteroptera: Pentatomidae) to gammacyhalothrin under laboratory condictions. Sci. Agric., 62, 478-482.

Pereira, A.I.A., Ramalho, F.S., Malaquias, J.B., Bandeira, C.M., Silva, J.P.S., Zanuncio, J.C. (2008), Density of Alabama argillacea larvae affects food extraction by females of Podisus nigrispinus. Phytoparasitica, 36, 8494.

Price, P.W. (1975), Insect ecology. New York: John Wiley and Sons. 514p.

Ramalho, F.S. (1994), Cotton Pest Management. Part 4. A Brazilian perspective. Annu. Rev. Entomol., 39, 563-578.

Rocha, L., Redaelli, L.R. and Steiner, M.G. (2002), Extração de alimento por Cosmoclopius nigroannulatus (Hemiptera: Reduviidae) de ninfas de Spartocera dentiventris (Hemiptera: Coreidae). Neotrop. Entomol., 31, 601-607.

SAS Institute. (2006), SAS User's Guide: Statistics. SAS Institute Inc., Cary, NC, USA.
Silva, E.N., Santos, T.M. and Ramalho, F.S. (1997), Consumo alimentar e crescimento do predador Supputius cincticeps (Stal)(Heteroptera: Pentatomidae) alimentando-se de lagartas de curuquerê-do-algodoeiro. An. Soc. Entomol. Brasil, 26, 349-357.

Thomas, D. B. (1992), Taxonomic synopsis of the Asopinae Pentatomidae (Heteroptera) of the Western Hemisphere. Entomological Society of America, Lanham, CA, USA.

Tostowaryk, W. (1972), The effect of prey defense on the functional response of Podisus modestus (Heteroptera: Pentatomidae) to densities of the sawflies Neodiprion swainei and $N$. pratti banksianae (Hymenoptera: Neodiprionidae). Can. Entomol., 104, 61-69.

Turnbull, A. L. (1962), Quantitative studies of the food of Linyphia triangularis Clerck (Araneae: Linyphiidae). Can. Entomol., 91, 1233-1250.

Waldbauer, G.P. (1968), The consumption and utilization of food by insects. Adv. Insect. Physiol., 5, 229-288.

Received: April 15, 2008; Revised: December 10, 2008; Accepted: October 01, 2009. 